\title{
Whole leaf photosynthetic light response in a carnivorous plant species Sarracenia alata
}

\author{
K.A. HOPKINS* and D.A. GRAVATT ${ }^{* *,+}$ \\ Texas A\&M University, Horticultural Science, College Station, 77843 Texas, USA* \\ Stephen F. Austin State University, Nacogdoches, 75962 Texas, USA ${ }^{* *}$
}

\begin{abstract}
Photosynthetic light-response curves of mature leaves of Sarracenia alata were generated and characterized using a custom built chamber $(2.79 \mathrm{~L})$ capable of accommodating whole leaves, or pitchers, coupled to a LI-COR $6400 X T$ Portable Photosynthesis System. In addition to generating light-response curves, chlorophyll content, leaf area, and dry mass measurements were obtained for each pitcher. Gas-exchange variables from the light-response curves are reported on a leaf area and dry mass basis. Calculated light-saturated photosynthesis was found to be $2.09 \mu \mathrm{mol}\left(\mathrm{CO}_{2}\right) \mathrm{m}^{-2} \mathrm{~s}^{-1}$ with a light-saturation point of $315.14 \mu \mathrm{mol}$ (photon) $\mathrm{m}^{-2} \mathrm{~s}^{-1}$, light-compensation point of $40.25 \mu \mathrm{mol}(\mathrm{photon}) \mathrm{m}^{-2} \mathrm{~s}^{-1}$, dark respiration rate of $-0.57 \mu \mathrm{mol}\left(\mathrm{CO}_{2}\right) \mathrm{m}^{-2} \mathrm{~s}^{-1}$, and apparent quantum efficiency of 0.033 . The use of a large custom built chamber proved to be successful and the data presented indicate that adequate mixing and sampling was achieved. This study is the first to document photosynthetic response of $S$. alta. The data from this study indicate that $S$. alata collected from our study site photosynthetically performed like that of a shade-adapted $\mathrm{C}_{3}$ plant and the measurements were consistent with those published for other species of Sarracenia.
\end{abstract}

Additional key words: chlorophyll; gas exchange; leaf morphology; respiration; stomatal conductance.

\section{Introduction}

Carnivorous plants typically grow in nutrient poor soil, usually with diffuse light and saturated soil conditions (Givnish et al. 1984, Brewer 2005). The various forms of traps allow the plants to capture and digest animal prey to gain nutrients that would otherwise be absorbed from a nutrient rich soil. The traps consist of modified leaves which take on various forms and function from species to species. Because the traps are modified leaves, the photosynthetic efficiency can be affected by the environment and nutrient availability (Pavlovič 2011). This includes species that have leaves that perform both photosynthesis as well as capturing prey. Some species are heterophyllous, meaning they have one type of leaf for photosynthesis, and another type of leaf specifically for the capture of prey (Pavlovič 2011). Some even have one part of the leaf designated for photosynthesis and another part of the leaf designated for prey capture (Pavlovič 2011). These adaptations allow carnivorous plants to thrive in an environment not habitable to most other plants which require a high level of nutrient gain from the soil.

There are several genera of carnivorous plants with pitfall traps, although they are not necessarily closely related. Though these plants do maintain their nutrient require- ments, especially nitrogen, by insect capture, it is now known that they are capable of growth without insect capture (Bruzzese et al. 2010) and thus rely solely on soil nutrients and photosynthetic carbon gain for growth and development. While there have been studies documenting how insect capture benefits the carnivorous plants (Givnish et al. 1984, Méndez and Karlsson 1999, Brewer et al. 2011, He and Zain 2012), little is known about the photosynthetic tendencies of many of the species, specifically Sarracenia alata Wood, pale pitcher plant.

The pitcher of Sarracenia alata is a modified leaf, tubular in shape, which functions as a trap, as well as being photosynthetic. The stomata of $S$. alata are sunken and are found in all parts of the pitcher (Jones 2008). The exterior surface of the pitcher has many stomata, $30.2 \pm 1.15 \mathrm{~mm}^{-2}$ (mean $\pm \mathrm{SE}$ ), signifying that it is the abaxial surface of the leaf primarily involved in photosynthetic carbon dioxide uptake. The internal surface of the pitcher has nectar glands present, as well as some stomata $\left(2.8 \pm 0.97 \mathrm{~mm}^{-2}\right)$ which are restricted to the inside of the upper lip (Jones 2008). Other parts of the pitcher have been found to exhibit different stomatal patterns. The lid of the pitcher was found to be amphistomatous (Jones 2008), having stomata on both abaxial $\left(21.4 \pm 1.71 \mathrm{~mm}^{-2}\right)$ and adaxial surfaces $\left(13.2 \pm 1.01 \mathrm{~mm}^{-2}\right)$. Overall, $S$. alata pitchers possess more

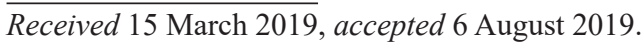

${ }^{+}$Corresponding author; e-mail: dgravatt@sfasu.edu

Abbreviations: $C_{\mathrm{i}}$ - internal carbon dioxide concentration; Chl - chlorophyll; DM - dry mass; $E$ - transpiration; FM - fresh mass; $g_{\mathrm{s}}-$ stomatal conductance for water vapor; $l_{\mathrm{c}}$ - light-compensation point; $l_{\mathrm{s}}$ - light-saturation point; $P_{\mathrm{Nmax}}-$ light-saturated net photosynthesis; $\alpha$ - apparent quantum efficiency.

Acknowledgements: This work was supported by a Mini-grant from the Office of Research and Sponsored Programs at Stephen F. Austin State University and the LEEF Program at LI-COR Inc. 
stomata on the exterior surface of the pitchers than the interior. Interestingly, the ones on the interior base of the pitcher are covered with digestive fluid and their function is unknown. Sarracenia alata, a pitcher plant native to regions in southeastern North America, produces a pitfall trap. Little is known about the physiology of these plants.

The morphology and physiology of a whole leaf is important for understanding the roles of leaf photosynthetic carbon gain in carnivorous plants. Photosynthetic characteristics have been examined on Sarracenia leucophylla and Sarracenia purpurea (Ellison and Gotelli 2002, Wakefield et al. 2005, Bruzzese et al. 2010, Hájek and Adamec 2010, Pavlovic 2011), but these previous studies focused on the photosynthetic gas exchange of the keel (Hájek and Adamec 2010) or excised portions of pitchers (Hájek and Adamec 2010) using a clamp-on type chamber. In $S$. leucophylla and S. purpurea photosynthetic measurements were recorded by attaching prefabricated chambers $(0.25 \mathrm{~L})$ on smaller, less than $15-\mathrm{cm}$ tall leaves (Bruzzese et al. 2010). To date, Sarracenia alata has yet to be characterized as to its photosynthetic characteristics. Using a custom 2.79-L chamber, the light-response curves generated in this study provide information for future research on the light limits and photosynthetic trends for whole leaves of $S$. alata.

Light-response curves provide valuable information regarding the photosynthetic characteristics of a species (Pessarakli 2005, Lobo et al. 2013). Information gleaned from light-response curves can indicate the plants adaptations to specific light environments. Studies have suggested that there is a trade-off between a maximum rate of photosynthesis $\left(P_{\text {Nmax }}\right)$ and a leaf designed to capture prey vis-a-vis a low rate of photosynthesis (Pavlovič 2011).

Standard chambers for photosynthesis can only measure relatively flat leaves or small whole plants. Manufacturersupplied chambers are readily available. However, none of them can accommodate a whole leaf of $S$. alata. Leaves of S. alata can measure up to $75 \mathrm{~cm}$ tall (Schnell 2002), but typically range $25-45 \mathrm{~cm}$, and 3-5 cm wide (McPherson 2007). The typical way in which leaves are measured is by inserting the flat leaf into a chamber. However, the only flat portion of a $S$. alata leaf that would fit into a chamber is the hood $\left(14-18 \mathrm{~cm}^{2}\right)$ or a narrow wing $(<5 \mathrm{~mm}$ wide) running the length of the hollow cylindrical leaf. Attempts to fit the wing into a standard leaf chamber proved unsuccessful. The hood does not accurately represent the entire leaf surface, which in this study was $150.73 \mathrm{~cm}^{2}$ (range 126-175 $\mathrm{cm}^{2}$ ). That is, the hood represents no more than $12 \%$ of the total leaf area. In addition, the hood is oriented in a horizontal plane which receives light at a more direct angle than that of the sides of the cylindrical leaf. For this reason, a custom chamber was designed to accommodate whole leaf gas-exchange measurement of $S$. alata in order to achieve a higher level of accuracy in measuring photosynthesis of these complex leaves.

\section{Materials and methods}

Field-collected plants and greenhouse conditions: Twenty-eight whole plants with rhizomes of $S$. alata were collected from a hill-side seep near Boykin Springs Lake in the Angelina National Forest located near Zavalla, Texas. This hill-side seep is found at $31.076478^{\circ} \mathrm{N}$ and $-94.279265^{\circ} \mathrm{W}$. Plants were sampled in late February 2015 while still dormant. After collection, the whole plants were individually transplanted into 2.5 -L plastic pots. Planting media consisted of $50 \%$ peat and $50 \%$ sand by volume. This media composition was chosen because it mimicked the natural soil found in this herbaceous seep from which the samples were collected. The sand allows for proper drainage while the peat allows for good aeration and for water to wick up from the water-filled tubs. Water levels were maintained at $10 \mathrm{~cm}$ or approximately halfway up the sides of the $2.5-\mathrm{L}$ pots. This water level was maintained throughout the experiment to mimic the natural herbaceous seep from which the samples were collected. These tubs were located in a greenhouse at Stephen F. Austin State University, Nacogdoches, Texas. The greenhouse was covered with a shade cloth $(50 \%)$ in order to reduce ambient solar radiation and to mimic the diffuse light that plants would normally be exposed to in the field. Greenhouse temperatures were maintained at a minimum of $18^{\circ} \mathrm{C}$ night time, minimum of $25^{\circ} \mathrm{C}$ during the day and with solar noon light intensity of $\sim 600 \mu \mathrm{mol}$ (photon) $\mathrm{m}^{-2} \mathrm{~s}^{-1}$ measured at the top of the plants.

Herbaceous seep light intensity: Light levels at the collection site were measured using a $\mathrm{Li}$-COR LI250A Light Meter coupled with a LI-191R Line Quantum Sensor (LI-COR, Inc., Lincoln, NE, USA). Four transects through two herbaceous seeps containing $S$. alata were established by randomly selecting a compass bearing through the sample area, each approximately $30 \mathrm{~m}$ in length (range of 28.5-33.0 m). Two transects were completed in the herbaceous seep in which the plants for this study were sampled and two in an herbaceous seep approximately $5 \mathrm{~km} \mathrm{NNW}$ of the first site. Both hillside seeps have a surrounding overstory of Pinus taeda mixed with a sparse shrub layer of Acer rubrum (red maple) and Magnolia virginiana (sweetbay magnolia), with an understory of Scleria spp. (nut-rushes), Andropogon spp. (bluestems), Aristida spp. (threeawn grasses), Panicum spp. (panic grasses), and Drosera rotundifolia (round-leaf sundew). Visual inspection indicated that both sites were comparable in terms of overstory and shrub-layer vegetation and overstory density. Light intensity was recorded along the transects with each encounter of a $S$. alata plant with the sensor array, perpendicular to each transect, at plus or minus $1 \mathrm{~h}$ around solar noon on two consecutive cloud free days in May 2015 for each of the herbaceous seeps.

Photosynthesis gas-exchange chamber design: The LI-6400XT Portable Photosynthesis System (PPS) was used to collect and analyze gas-exchange data from the sampled pitcher traps. A custom made chamber, capable of enclosing the whole leaf (pitcher), was attached to the LI-6400XT PPS. Available chambers for this instrument are limited to a single flat leaf of no more than $\sim 4 \mathrm{~cm}$ by $\sim 6 \mathrm{~cm}$ or a chamber having a volume of $0.25 \mathrm{~L}$. Having 
a larger chamber allowed for taller leaves to be sampled, and also accommodated the tubular-shaped pitchers of $S$. alata. The use of a custom chamber did create some potential obstacles and sources of error ( $L I-C O R$, Application Note \#3). These were acceptable risks for this experiment due to desire to sample the larger sized leaves of S. alata. Precautions were taken to eliminate or ameliorate problems as discussed in the following section. Sources of errors included the increased potential for air leaks because of the large internal surface area with an increased number and length of joints. The use of cylindrical material eliminated edges and corners associated with a rectangular designed chamber that could be potential sources of leaks. The larger internal volume, meant that longer periods of time were required for measurement stabilization. The larger internal surface area also increased the potential for sorption of water vapor to the polycarbonate material. This was important if attempts are made to measure variables related to water vapor content. Clear teflon tape was applied to all internal surfaces to reduce the possibility of water sorption to the chamber walls. The larger volume and the necessity to insure proper mixing of air was addressed by installing a pair of internal fans sealed within the chamber to move and mix the air. Additional time between light levels helped assure stability and accurate measurements of photosynthesis were recorded during the experiment.

The gas-exchange chamber for this experiment was of our own design (Fig. 1A). The $0.635 \mathrm{~cm}$ thick cylindrical gas-exchange chamber was constructed out of $10.16 \mathrm{~cm}$ outside diameter $(8.89 \mathrm{~cm}$ inside diameter $)$ polycarbonate tubing, $45 \mathrm{~cm}$ in length for a calculated internal volume of $2793 \mathrm{~cm}^{3}$. Cemented to the inside of the chamber were two 12-V micro fans (MagLev, model MC25101V2000V-A99 12-volt DC miniature fan, Sunon Inc., USA) to insure good mixing of the air inside the chamber and powered by an external $12-\mathrm{V}$ DC power supply. An opening was created to allow the running of external wires to a $12-\mathrm{V}$ power source to supply power the fans and sealed using silicon sealant. The top of the gas chamber was sealed with a onepiece disc of $1.61-\mathrm{cm}$ polycarbonate using polycarbonate cement. All interior surfaces were lined with clear teflon provided by LI-COR Bioscience (Lincoln, NE, USA) to minimize water sorption. The bottom of the gas chamber consisted of a two-piece $1.61-\mathrm{cm}$ polycarbonate disc that was used to seal around the base of the pitcher plant leaf with Fun-Tak reusable adhesive putty (Dap Products Inc., Baltimore, MD). A hole was drilled into the side of the custom chamber to allow for the insertion of a fine copper/ constantan thermocouple to measure leaf temperatures (Omega Engineering, Inc., Stamford, Connecticut, USA). The thermocouple was mounted on a small wooden dowel (2 $\mathrm{mm}$ diameter) to allow the thermocouple to make contact with the leaf surface. The protocol for using the LI-COR LI-6400XT PPS followed that outlined in the LI-COR Application Note \#3 (LI-COR, Inc.) and measurement parameters were set using the instrument software, per manufactures recommendations for custom chambers. Air flow through the chamber was set to the maximum provided by the instrument, $700 \mu \mathrm{mol} \mathrm{s}^{-1}$.

The external light source for our system was designed

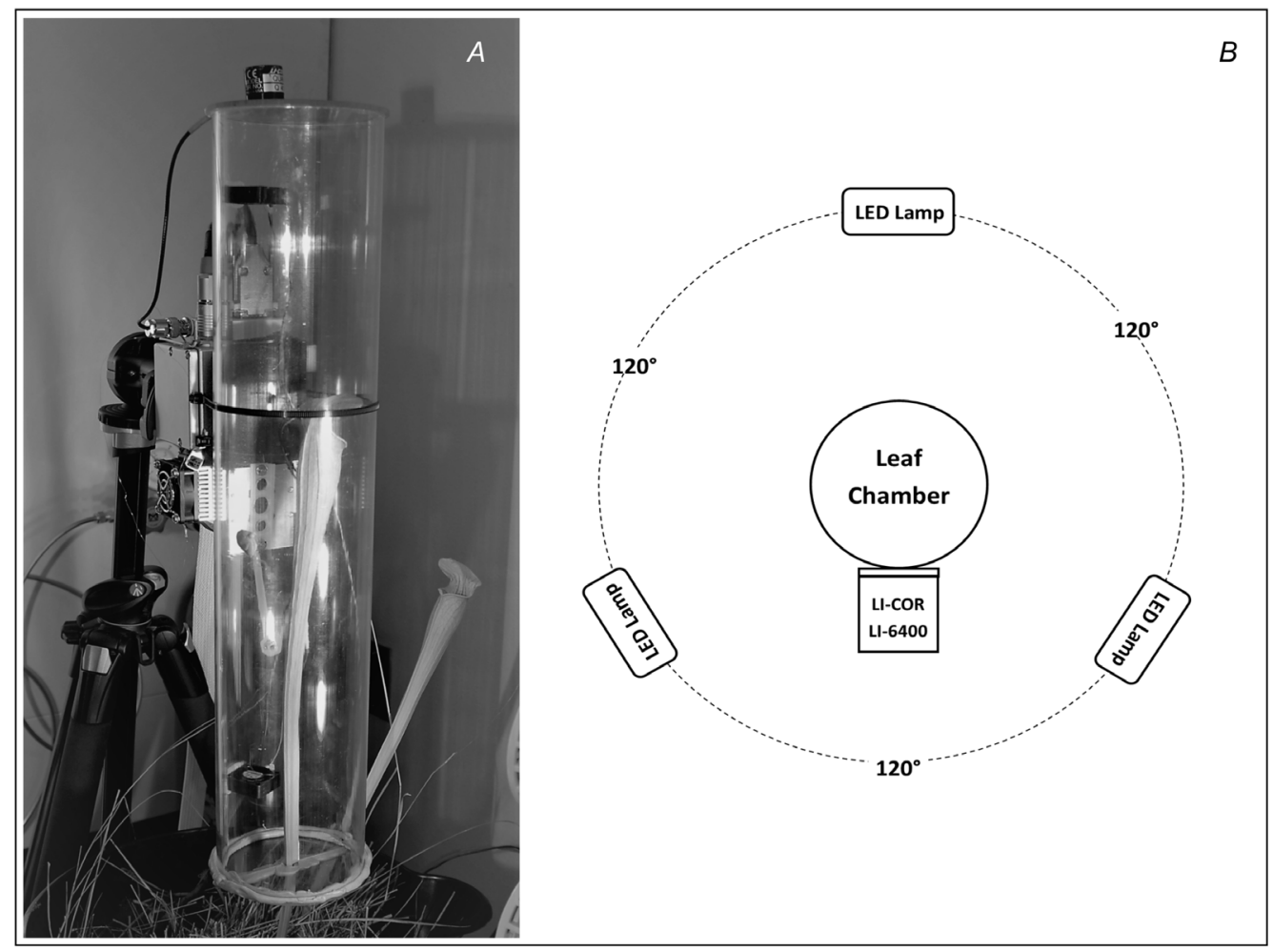

Fig 1. Custom 2.79-L polycarbonate chamber with a pitcher of Sarracenia alata sealed in the chamber $(A)$. Three $6500 K$ LED light bars placed at $120^{\circ}$ angles from each other, surrounding the chamber, so that the chamber would be illuminated from all sides $(B)$. 
to illuminate the entire length of the gas chamber, as well as all sides of the gas-exchange chamber. Light was provided using three 61-cm BML Horticulture (Austin, Texas) $L E D 6500 \mathrm{~K}$ light bars vertically mounted on horizontally adjustable stands. These fixtures deliver high PAR levels and are assembled with 6500 Kelvin Cool White LEDs. Light fixtures were arranged around the chamber at $120^{\circ}$ from each other (Fig. 1B).

Preparation of plants for measurement: Before testing, the water and digestive enzymes of the pitcher were removed using flexible tubing and a hollow glass tube attached to vacuum pump, followed by a rinse of deionized water. Removal of the pitcher contents eliminated the possibility of $\mathrm{CO}_{2}$ exchange between the liquid water and the chamber environment. It also eliminated the possibility of $\mathrm{CO}_{2}$ release by digestion of organisms affecting the measurement of $\mathrm{CO}_{2}$ assimilated during the photosynthesis process.

Photosynthetic gas-exchange measurements: For this study, each whole leaf, or hereafter referred to as a pitcher, was used to generate a single light-response curve. Each fully mature, greenhouse grown pitcher was carefully inserted into the bottom of the chamber and sealed. A total of thirteen pitchers were sampled. The thirteen light-response curves were analyzed and reported as baseline data for the characterization of photosynthesis in this species.

During the measurements, carbon dioxide concentrations in the chamber were controlled by the LI-6400XT Portable Photosynthesis system and were maintained at $400 \mathrm{ppm} \mathrm{CO}_{2}$ throughout the study for all pitchers. Relative humidity inside the leaf chamber was maintained at $40 \%$, in order to mimic the relative humidity of the herbaceous seep. The temperature inside the chamber was maintained at room temperature of $22-23^{\circ} \mathrm{C}$. The light intensity was increased step-wise through eight levels ranging from dark $\left[0 \mu \mathrm{mol}\left(\right.\right.$ photon) $\left.\mathrm{m}^{-2} \mathrm{~s}^{-1}\right]$ to saturated $[1,200 \mu \mathrm{mol}$ (photon) $\mathrm{m}^{-2} \mathrm{~s}^{-1}$ ] using the manufacture's provided rheostat. Light levels were adjusted to the selected light intensities measured by a $L I-C O R L I-250 A$ light meter using a $L I-C O R$ $L I-190 R$ quantum senor. Light intensity was checked horizontally at three radial locations, 0,120 , and $240^{\circ}$, and vertically at the top, middle, and bottom of the leaf each time the light levels were changed. Dark respiration rate was determined first by covering the chamber with a dark cloth to ensure the exclusion of any light for at least $30 \mathrm{~min}$. The cover was removed and the lowest level of light, $50 \mu \mathrm{mol}$ (photon) $\mathrm{m}^{-2} \mathrm{~s}^{-1}$, was applied to the leaf. The light intensity was increased to the next level to obtain a second data point after waiting for stabilization of measurement conditions. This procedure was repeated until gas-exchange measurements at all eight light intensities were completed, i.e., 50, 100, 200, 400, 800, 1,000; and 1,200 $\mu \mathrm{mol}$ (photon) $\mathrm{m}^{-2} \mathrm{~s}^{-1}$. Each step of the light-response curves lasted approximately 10-12 min with data for a single leaf taking no more than 90 min to collect.

Once the light curve was obtained, the pitcher was removed from the chamber, cut from the plant, and the fresh mass (FM) recorded. Following the fresh mass measurement, the pitcher was cut longitudinally and laid open flat so that the total surface area could be measured using a LI-3100C Area Meter (LI-COR Inc.). Following leaf surface area determination, leaf discs were obtained from the pitcher using a standard office, single-hole punch and used for Chl content analysis. Five leaf discs from the hood, and five leaf discs from the body of the pitcher were collected. After the Chl content was measured, the leaf discs and the remainder of the pitcher were placed in a drying oven at $100^{\circ} \mathrm{C}$ for a $24-48 \mathrm{~h}$. Following drying, pitcher dry mass (DM) was recorded after combining pitchers with their respective leaf discs.

Leaf chlorophyll (Chl) content: Leaf $\mathrm{Chl} a, b$, and total $(a+b)$ content were determined using published methods (Inskeep and Bloom 1985) employing N,N-dimethylformamide (DMF). Leaf discs from the hood and body of the pitcher were placed in separate glass vials with $5 \mathrm{ml}$ of the DMF buffer. These were left to incubate in the dark at $4^{\circ} \mathrm{C}$ for at least $48 \mathrm{~h}$. Once $\mathrm{Chl}$ was extracted, the samples were allowed to reach room temperature. At room temperature, samples were placed in a cuvette and the absorption of the extract was recorded using a spectrophotometer (Beckman DU-640, Beckman Instruments, Inc., USA) at 647, 665, and $750 \mathrm{~nm}$. Chl content was calculated using the spectrophotometric data using published extinction coefficients (Inskeep and Bloom 1985). The leaf discs that remained were placed in a $100^{\circ} \mathrm{C}$ oven and allowed to dry overnight, weighed, and recorded.

Data and statistical analysis: The measured photosynthetic light-response data were fitted with a quadratic equation using available software from $L I-C O R$, Lincoln, NE [Photosynthesis Workbench, 1.0.0.770, AQ (Light Response) Curve for Photosynthesis, 2005] running under Microsoft Windows. This software yields light saturation, light compensation, quantum efficiency, convexity, dark respiration, and maximum photosynthesis values. Such light-response curves have been generated previously described by Norman et al. (1992) and utilized for ferns (Yiotis et al. 2017) and for Pinus densiflora (Azuma et al. 2019). Light-response curves were described by the equation used by Norman et al. (1992):

$$
\mathrm{A}=\frac{\phi \mathrm{Q}_{\mathrm{a}}}{\left[1+\left(\frac{\phi \mathrm{Q}_{\mathrm{a}}}{\mathrm{A}_{\max }}\right)^{\mathrm{p}}\right]^{1 / \mathrm{p}}}+\mathrm{A}_{\mathrm{o}}
$$

where $\mathrm{Q}_{\mathrm{a}}$ gives the absorbed quanta per unit leaf area in the chamber $\left[\mu \mathrm{mol}\right.$ (photon) $\left.\mathrm{m}^{-2} \mathrm{~s}^{-1}\right], \phi$ is the photochemical efficiency at low light levels, $\mathrm{A}_{\max }$ is the assimilation rate at light saturation $\left[\mu \mathrm{mol}\left(\mathrm{CO}_{2}\right) \mathrm{m}^{-2} \mathrm{~s}^{-1}\right], \mathrm{A}_{o}$ is the dark assimilation rate $\left[\mu \mathrm{mol}\left(\mathrm{CO}_{2}\right) \mathrm{m}^{-2} \mathrm{~s}^{-1}\right]$, and $\mathrm{p}$ is a curvature parameter. $Q_{a}$ is given as follows (Norman et al. 1992): $\mathrm{Q}_{\mathrm{a}}=\alpha_{\mathrm{par}} \tau_{\mathrm{c}} \mathrm{Q}$, where $\alpha_{\mathrm{par}}$ is leaf absorptivity (PAR), $\tau_{\mathrm{c}}$ is chamber transmittance and $\mathrm{Q}$ is quanta $[\mu \mathrm{mol}($ photon) $\left.\mathrm{m}^{-2} \mathrm{~s}^{-1}\right]$.

As a validation of the $L I-C O R$ program, a subset of 
the photosynthetic light-response curves were fitted by a colleague, who was not involved in this study, by means of a nonrectangular hyperbola using Photosyn Assistant software version 1.1 (Dundee Scientific, Dundee, UK). This program followed the model proposed by Farquhar et al. (1980) and yielded results very similar to those calculated by LI-COR software. Photosyn Assistant is apparently no longer available for purchase and thus the determination was made to use the $L I-C O R$ program, specifically the AQ Curve for Photosynthesis menu option.

$J M P$ software by $S A S$ (Cary, NC) was used for statistical analysis of the pitcher morphology, gas-exchange data, and Chl concentration data. JMP distributions routines were performed to get mean and standard error values for pitcher characteristics including leaf area, fresh mass, dry mass, fresh mass to dry mass ratio, and water content of tissue. $J M P$ software was used to obtain descriptive statistics for the following gas-exchange variables: mean and standard error values for light-saturated net photosynthesis $\left(P_{\mathrm{Nmax}}\right)$, light-saturation point $\left(l_{\mathrm{s}}\right)$, light-compensation point $\left(l_{\mathrm{c}}\right)$, dark respiration $\left(R_{\mathrm{D}}\right)$, and maximum quantum yield $(\alpha)$. Analysis of performance ( $A N O V A$ ) was performed on Chl content data from the hood and body to detect differences in Chl $a, \mathrm{Chl} b$, and total Chl $(a+b)$ on both a leaf area and dry mass basis. Further fit of least squares tests (McDonald 2014) were run on Chl data to detect differences in Chl content between the hood and body for both leaf area and dry mass.

\section{Results}

Herbaceous seep ambient light levels: Transects measuring midday, ambient light intensity, from two different herbaceous seeps containing $S$. alata were performed in mid-July 2015. Mean ( \pm SE) light intensity for the herbaceous seeps in which the plants were sampled for gas-exchange work was $495 \pm 81 \mu \mathrm{mol} \mathrm{m}^{-2} \mathrm{~s}^{-1}$ (range 40-1,420 $\mu \mathrm{mol} \mathrm{m} \mathrm{m}^{-2} \mathrm{~s}^{-1}$ ) and that of the neighboring seep was $497 \pm 58 \mu \mathrm{mol} \mathrm{m}^{-2} \mathrm{~s}^{-1}$ (range $93-1,720 \mu \mathrm{mol} \mathrm{m}^{-2} \mathrm{~s}^{-1}$ ).

Leaf morphology: Pitcher leaves in this study ranged in height from 30 to $40 \mathrm{~cm}$ and had a width at the top of the pitcher from 3.5 to $5.5 \mathrm{~cm}$. Mean leaf area for all samples was $150.73 \mathrm{~cm}^{2}$ (Table 1). Mean pitcher fresh mass was $5.44 \mathrm{~g}$ and mean dry mass was $1.11 \mathrm{~g}$. Pitcher mean fresh mass to dry mass ratio was $4.9 \mathrm{~g}$ with a mean leaf water content of $79 \%$. The ranges and standard error of the mean can be found in Table 1.

Photosynthetic gas-exchange characterization: Collection of light-response data typically required two hours to complete with each step-wise increase in light intensity needing a $12-18$ min acclimation period to reach steadystate conditions for internal $\mathrm{CO}_{2}$ concentration and transpiration rate. Composite light-response curve for all thirteen pitchers tested can be found in Fig. 2. The solid line represents the mean gas exchange for all pitchers $(n=13)$.

Table 1. Characteristics of the leaves of Sarracenia alata used for photosynthetic measurements. Data are presented as means $\pm \operatorname{SE}(n=13)$.

\begin{tabular}{llllll}
\hline & Leaf area $\left[\mathrm{cm}^{2}\right]$ & Fresh mass $[\mathrm{g}]$ & Dry mass $[\mathrm{g}]$ & Fresh mass/Dry mass ratio & Water content [\%] \\
\hline Mean & $150.73 \pm 11.37$ & $5.44 \pm 0.53$ & $1.11 \pm 0.09$ & $4.90 \pm 0.24$ & $79.0 \pm 0.9$ \\
Range & $126.74-174.73$ & $4.32-6.56$ & $0.92-1.31$ & $4.39-5.41$ & $76-81$ \\
\hline
\end{tabular}

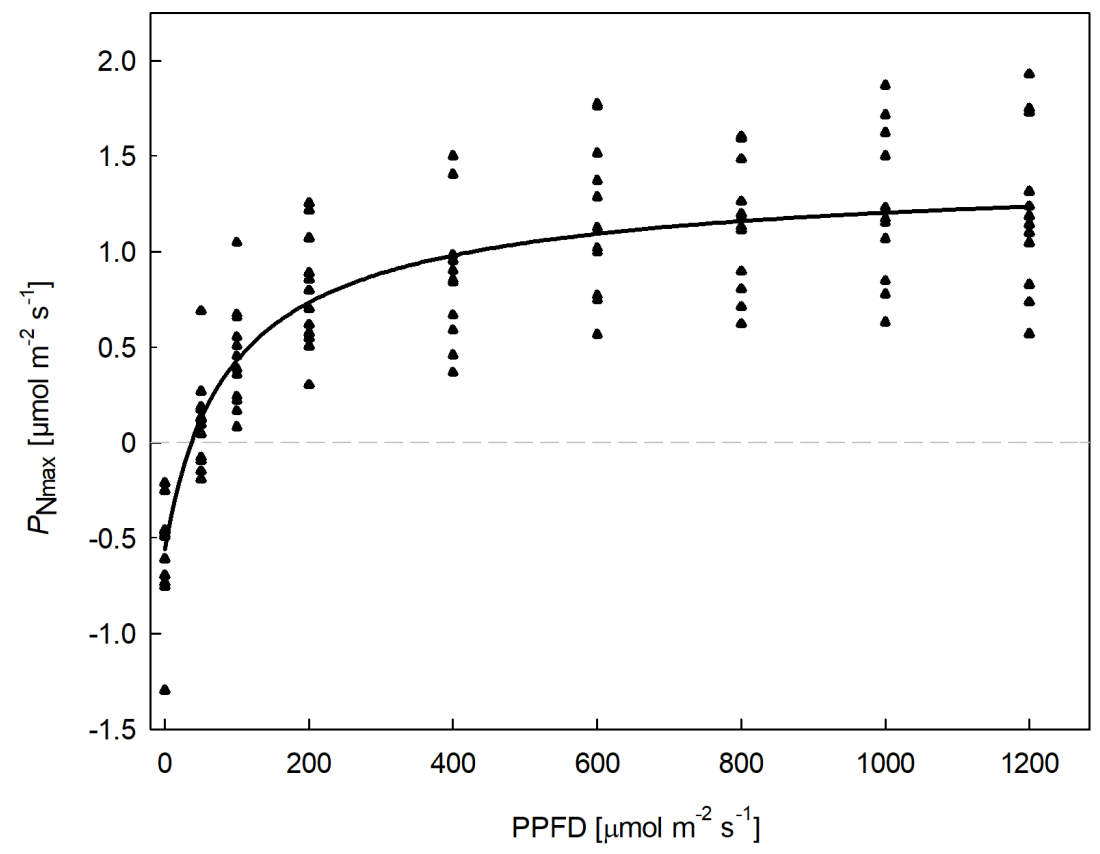

Fig. 2. Photosynthetic light-response curve for whole leaves of Sarracenia alata $(n=13)$. Solid line represents combined data fitted to a nonrectangular hyperbolic function. 
Light-response curves using a custom chamber, attached to the LI-COR LI-6400XT, yielded meaningful data concerning the gas exchange of Sarracenia alata. Mean light saturated net photosynthesis $\left(P_{\mathrm{Nmax}}\right)$ was $267.04 \mu \mathrm{mol}$ $\mathrm{g}^{-1}(\mathrm{DM})$, on a leaf dry mass basis, and $2.09 \mu \mathrm{mol}\left(\mathrm{CO}_{2}\right)$ $\mathrm{m}^{-2} \mathrm{~s}^{-1}$ on a leaf area basis (Table 2).

The mean light-saturation point was found to be $315.14 \mu \mathrm{mol} \mathrm{m}{ }^{-2} \mathrm{~s}^{-1}$ (Table 2). Light compensation point is the point where the amount of $\mathrm{CO}_{2}$ produced by cellular respiration is equal to the amount of $\mathrm{CO}_{2}$ assimilated for photosynthesis. Mean light-compensation point was $48.9 \mu \mathrm{mol} \mathrm{g}^{-1}(\mathrm{DM}) \mathrm{s}^{-1}$, on a dry mass basis, and $40.25 \mu \mathrm{mol}$ $\mathrm{m}^{-2} \mathrm{~s}^{-1}$ on a leaf area basis (Table 2). Mean dark respiration $\left(R_{\mathrm{D}}\right)$ rates were $72.30 \mu \mathrm{mol} \mathrm{g} \mathrm{g}^{-1}(\mathrm{DM})$, on a dry mass basis, and $0.57 \mu \mathrm{mol}\left(\mathrm{CO}_{2}\right) \mathrm{m}^{-2} \mathrm{~s}^{-1}$ on a leaf area basis (Table 2).

Apparent quantum yield $(\alpha)$, the slope of the initial light-dependent portion of the light-response curve, was $0.033 \mathrm{~mol}\left(\mathrm{CO}_{2}\right.$ assimilated $)$ per photons absorbed. Pitcher photosynthetic light-saturated $\left[1,000 \mu \mathrm{mol}\right.$ (photon) $\left.\mathrm{m}^{-2} \mathrm{~s}^{-1}\right]$ gas-exchange characteristics can be found in Table 3 . Stomatal conductance was $0.045 \mathrm{~mol}\left(\mathrm{H}_{2} \mathrm{O}\right) \mathrm{m}^{-2} \mathrm{~s}^{-1}$, intercellular $\mathrm{CO}_{2}$ concentration $\left(C_{\mathrm{i}}\right)$ was $308.68 \mu \mathrm{mol} \mathrm{mol}^{-1}$, and transpiration was $0.622 \mathrm{mmol}\left(\mathrm{H}_{2} \mathrm{O}\right) \mathrm{m}^{-2} \mathrm{~s}^{-1}$.

Leaf Chl content: The hood of the pitcher had significantly higher Chl $a$, Chl $b$, and total Chl, on a dry mass basis, than that of the body (Table 4). On a per leaf area basis, only the hood had significantly higher $\mathrm{Chl} b$ content, $8.46 \mathrm{mg} \mathrm{cm}^{-2}$, than that of the body which had $5.19 \mathrm{mg} \mathrm{cm}^{-2}$. Mean Chl $a$ to $\mathrm{Chl} b$ ratio was significantly greater in the body of the pitcher (Table 4).

\section{Discussion}

A total of 13 pitchers (whole leaves) were sampled for gas exchange in this study. The custom built chamber was quite successful in obtaining gas-exchange measurements of the whole leaf. The mean light-response curves (Fig. 2) obtained with the use of a custom chamber yielded results comparable to the study by Bruzzese et al. (2010) and was consistent with their works that concluded Sarracenia spp. response to light follows a nonrectangular hyperbolic curve. Light-saturated photosynthetic rates were comparable to previous studies (Ellison and Gotelli 2002, Wakefield et al. 2005, Bruzzese et al. 2010, Hájek and Adamec 2010, Pavlovič 2011).

Dark respiration rates $\left(R_{\mathrm{D}}\right)$ for whole leaves, on a leaf area basis, revealed that $S$. alata had dark respiration rates of $-0.57 \mu \mathrm{mol}\left(\mathrm{CO}_{2}\right) \mathrm{m}^{-2} \mathrm{~s}^{-1}$. This is lower than that found for S. leucophylla reported by Bruzzese et al. (2010), $-1.44 \mu \mathrm{mol} \mathrm{m} \mathrm{m}^{-2} \mathrm{~s}^{-1}$. The $R_{\mathrm{D}} / P_{\mathrm{Nmax}}$ ratio was 27.0 and is higher than that reported by Hájek and Adamec (2010), 14.7 and 21.1, for pitcher wings and excised leaf wall tissue, respectively, in $S$. purpurea. Our ratio is higher than that in Hájek and Adamec (2010) and was taken at similar leaf temperatures. It appears that the higher $R_{\mathrm{D}} / P_{\mathrm{Nmax}}$

Table 2. Light-saturated net photosynthesis $\left(P_{\mathrm{Nmax}}\right)$, light-saturation point $\left(l_{\mathrm{s}}\right)$, light-compensation point $\left(l_{\mathrm{c}}\right)$, dark respiration $\left(R_{\mathrm{D}}\right)$, and apparent quantum efficiency $(\alpha)$ of Sarracenia alata based on leaf area and dry mass basis. Data are presented as means $\pm \operatorname{SE}(n=13$, respiration $n=12$ ).

\begin{tabular}{lcccccc}
\hline & $P_{\mathrm{N} \max }\left[\mu \mathrm{mol} \mathrm{m}{ }^{-2}\left(\mathrm{or} \mathrm{g}^{-1}\right) \mathrm{s}^{-1}\right]$ & $l_{\mathrm{s}}\left[\mu \mathrm{mol} \mathrm{m}^{-2} \mathrm{~s}^{-1}\right]$ & $l_{\mathrm{c}}\left[\mu \mathrm{mol} \mathrm{m}^{-2} \mathrm{~s}^{-1}\right]$ & $R_{\mathrm{D}}\left[\mu \mathrm{mol} \mathrm{m}{ }^{-2}\left(\mathrm{or} \mathrm{g}^{-1}\right) \mathrm{s}^{-1}\right]$ & $R_{\mathrm{D}}\left[\%\right.$ of $\left.P_{\mathrm{Nmax}}\right]$ & $\alpha$ \\
\hline Leaf area & $2.09 \pm 0.21$ & $315.1 \pm 24.4$ & $40.25 \pm 5.36$ & $-0.57 \pm 0.08$ & $27.0 \pm 0.14$ & $0.033 \pm 0.007$ \\
Dry mass & $267.04 \pm 17.28$ & $315.1 \pm 24.4$ & $48.90 \pm 5.08$ & $-72.30 \pm 7.65$ & $27.0 \pm 0.14$ & - \\
\hline
\end{tabular}

Table 3. Whole leaf gas-exchange parameters for light saturation $\left(l_{\mathrm{c}}\right)$, stomatal conductance to water $\left(g_{\mathrm{s}}\right)$, internal $\mathrm{CO}_{2}$ concentration $\left(C_{\mathrm{i}}\right)$, transpiration $(E)$ at light saturation $\left[1,000 \mu \mathrm{mol}\left(\right.\right.$ photon) $\left.\mathrm{m}^{-2} \mathrm{~s}^{-1}\right]$ of Sarracenia alata. Data are presented as means $\pm \mathrm{SE}(n=12)$.

\begin{tabular}{lllll}
\hline & $l_{\mathrm{c}}\left[\mu \mathrm{mol}(\right.$ photon$\left.) \mathrm{m}^{-2} \mathrm{~s}^{-1}\right]$ & $g_{\mathrm{s}}\left[\mathrm{mol}\left(\mathrm{H}_{2} \mathrm{O}\right) \mathrm{m}^{-2} \mathrm{~s}^{-1}\right]$ & $C_{\mathrm{i}}\left[\mu \mathrm{mol} \mathrm{mol}^{-1}\right]$ & $E\left[\mathrm{mmol}\left(\mathrm{H}_{2} \mathrm{O}\right) \mathrm{m}^{-2} \mathrm{~s}^{-1}\right]$ \\
\hline Mean & $315.14 \pm 24.40$ & $0.045 \pm 0.006$ & $308.68 \pm 10.11$ & $0.62 \pm 0.07$ \\
Range & $290.74-339.54$ & $0.033-0.058$ & $286.40-330.94$ & $0.46-0.78$ \\
\hline
\end{tabular}

Table 4. Chlorophyll concentration for the hood and body portions of the pitcher leaves of Sarracenia alata. Values within the same row not connected by the same letter are significantly different $(p<0.001)$. Data are presented as means $\pm \mathrm{SE}$.

\begin{tabular}{llcc}
\hline & & Hood & Body \\
\hline Leaf area basis $\left[\mathrm{mg} \mathrm{cm}^{-2}\right]$ & $\mathrm{Chl} a$ & $14.10 \pm 1.08^{\mathrm{A}}$ & $6.54 \pm 0.72^{\mathrm{A}}$ \\
$(n=17)$ & $\mathrm{Chl} b$ & $8.46 \pm 0.89^{\mathrm{A}}$ & $5.19 \pm 0.22^{\mathrm{B}}$ \\
& $\mathrm{Chl}(a+b)$ & $22.55 \pm 1.86^{\mathrm{A}}$ & $21.73 \pm 0.92^{\mathrm{A}}$ \\
Dry mass basis $\left[\mathrm{mg} \mathrm{g}^{-1}(\mathrm{DM})\right]$ & $\mathrm{Chl} a$ & $5,511.13 \pm 491.56^{\mathrm{A}}$ & $3,370.41 \pm 191.52^{\mathrm{B}}$ \\
$(n=16)$ & $\mathrm{Chl} b$ & $3,379.19 \pm 383.41^{\mathrm{A}}$ & $1,053.40 \pm 56.44^{\mathrm{B}}$ \\
& $\mathrm{Chl}(a+b)$ & $8,887.58 \pm 835.27^{\mathrm{A}}$ & $4,422.65 \pm 245.55^{\mathrm{B}}$ \\
Chl $a / b$ ratio & & $1.85 \pm 0.17^{\mathrm{A}}$ & $3.19 \pm 0.05^{\mathrm{B}}$ \\
\hline
\end{tabular}


ratio is the result of lower $P_{\mathrm{Nmax}}$ in $S$. alata compared to S. purpurea.

The light-compensation point of $S$. alata [40.25 $\mu$ mol(photon) $\mathrm{m}^{-2} \mathrm{~s}^{-1}$ ] was similar to that reported by Bruzzese et al. (2010) for S. leucophylla [43.6 $\mu$ mol(photon) $\mathrm{m}^{-2} \mathrm{~s}^{-1}$. In contrast, our light-compensation point was much higher than that reported for phyllodes of $S$. leucophylla or excised leaf portions of $S$. purpurea, 14.1 and $16.1 \mu \mathrm{mol}\left(\right.$ photon) $\mathrm{m}^{-2} \mathrm{~s}^{-1}$, respectively (Hájek and Adamec 2010). These two previous studies, Bruzzese et al. (2010) and Hájek and Adamec (2010), reported growing conditions of greenhouse plants at about $10 \%$ of full sunlight, $125 \mu$ mol(photon) $\mathrm{m}^{-2} \mathrm{~s}^{-1}$ and $10.3 \%$ of full sunlight, respectively. Growing conditions for their plants were about one-third of the light intensity that the plants in this study were grown. The increased light intensity under which our plants were grown could explain the increased light-compensation point.

Whole leaf quantum yield $\left(\alpha, \mathrm{CO}_{2}\right.$ fixed/photons absorbed by the leaf) in $S$. alata was found to be 0.033 mol mol ${ }^{-1}$ and is comparable to that reported by Bruzzese et al. (2010), $0.027 \mathrm{~mol} \mathrm{~mol}^{-1}$ for $S$. leucophylla but lower than found by Hájek and Adamec (2010) for S. leucophylla phyllodes $\left(0.065 \mathrm{~mol} \mathrm{~mol}^{-1}\right)$ or excised leaf portions from $S$. purpurea, $0.060 \mathrm{~mol} \mathrm{~mol}^{-1}$. Phyllodes are the modified petiole of the pitcher leaves. This study only included a small part of the phyllodes (Fig. 1A). Casual observations noted that phyllodes were darker green in color and thus, may contain more $\mathrm{Chl}$ and may be physiologically different than the remaining part of the leaf.

Sarracenia alata has similar photosynthetic lightresponse parameters as reported for S. leucophylla and S. purpurea (Bruzzese et al. 2010, Hájek and Adamec $2010)$. Light saturation of photosynthesis $\left(l_{\mathrm{s}}\right)$ for $S$. alata was at $315.14 \mu \mathrm{mol}$ (photon) $\mathrm{m}^{-2} \mathrm{~s}^{-1}$ and comparable with that found by Hájek and Adamec (2010) that reported light saturation for both $S$. leucophylla and S. purpurea to be between 242-307 $\mu \mathrm{mol} \mathrm{m} \mathrm{m}^{-2} \mathrm{~s}^{-1}$. Mean light saturation for $S$. alata found in this study is consistent with that found for terrestrial plants (Böhning and Burnside 1956, Pearcy and Ehleringer 1984, Lombardini et al. 2009), and characteristic of many carnivorous plants (Bruzzese et al. 2010, Hájek and Adamec 2010).

Calculated light-saturated net photosynthesis $\left(P_{\mathrm{Nmax}}\right)$ was $2.09 \mu \mathrm{mol}\left(\mathrm{CO}_{2}\right) \mathrm{m}^{-2} \mathrm{~s}^{-1}$ for $S$. alata. Hájek and Adamec (2010) reported greater values for light-saturated net photosynthesis $\left(P_{\mathrm{N} \max }\right)$ for both $S$. leucophylla and $S$. purpurea, between 3.97-5.32 $\mu \mathrm{mol}\left(\mathrm{CO}_{2}\right) \mathrm{m}^{-2} \mathrm{~s}^{-1}$. Lightsaturated net photosynthesis $\left(P_{\mathrm{N} \max }\right)$ for $S$. alata reported here was low. However, these results support studies that suggest there is a trade-off between maximum rate of photosynthesis $\left(P_{\text {Nmax }}\right)$ and a leaf designed to capture prey (Pavlovič 2011). The results of our study support the prevalence of low maximal photosynthetic rates in carnivorous plants. Arguably, low photosynthetic rates in greenhouse-grown plants in this study could be attributed to growth at lower than ambient light levels. However, mean light intensities recorded in the field from where our plants were collected was $495 \mu \mathrm{mol}$ (photon) $\mathrm{m}^{-2} \mathrm{~s}^{-1}$ (range $\left.40-1,420 \mu \mathrm{mol} \mathrm{m}^{-2} \mathrm{~s}^{-1}\right)$, which indicates our greenhouse light levels were comparable with that found in the field at $600 \mu \mathrm{mol}$ (photon) $\mathrm{m}^{-2} \mathrm{~s}^{-1}$.

Chl $a$ and $b$ content was significantly higher in the hood than that of the body of the pitcher (Table 4). This may be because the hood has more perpendicular light rays reaching it, as compared to the body, which is vertical and therefore does not get as much direct sunlight as the hood. Further research would be necessary to determine if the hood receives more direct light than the pitcher body. The $\mathrm{Chl} a / b$ ratio was greater in the body at $3.19 \mathrm{mg} \mathrm{g}^{-1}(\mathrm{DM})$ than that found in the hood, $1.85 \mathrm{mg} \mathrm{g}^{-1}(\mathrm{DM})$. Since the body of the pitcher makes up the majority of the leaf, it could be a better representation of the Chl content in S. alata.

Light is an important environmental factor that affects the Chl content in plants (Mielke et al. 2010). The Chl $a / b$ ratio can be a determining factor in deciding whether a plant is adapted for shade or full sun environments (Dale and Causton 1992). The low Chl $a / b$ ratio of $S$. alata, 1.85 in the hood is suggestive of sun-adapted tissue while that of the body, 3.19, is indicative of shade-adapted tissue (Anderson 1988). In general, leaves developed in shade contain more $\mathrm{Chl}$ and have a lower $\mathrm{Chl} a / b$ ratio than leaves that are developed in full sun (Mielke et al. 2010). This pattern was seen in our Chl results (Table 4). The hood is a horizontal surface which would receive maximum amounts of light, while the pitcher wall would receive less light as incident rays result in less light reaching the vertical leaf surfaces of the pitcher.

In $\mathrm{C}_{3}$ photosynthesis, increasing $C_{\mathrm{i}}$ concentrations will be stimulated over a much broader range when compared to $\mathrm{C}_{4}$ photosynthesis (Pearcy and Ehleringer 1984). In $\mathrm{C}_{3}$ plants, $\mathrm{CO}_{2}$ saturation does not occur until much higher intercellular $\mathrm{CO}_{2}$ concentrations $\left(C_{\mathrm{i}}\right)$ are present. Mean $C_{i}$ was relatively high, $308.68 \mu \mathrm{mol} \mathrm{mol}{ }^{-1}$, when compared to the values reported by Pearcy and Ehleringer (1984) for plants having the $\mathrm{C}_{3}$ pathway of photosynthesis but within the normal range for plants utilizing the $\mathrm{C}_{3}$ pathway. Transpiration and conductance values for $S$. alata are comparable with $\mathrm{C}_{3}$ plant reported by Pearcy and Ehleringer (1984). Gas-exchange data gathered on S. alata are consistent with that found in $\mathrm{C}_{3}$ plants.

Overall, the data provided by the light-response curves for greenhouse-grown $S$. alata indicate that this species is much like S. leucophylla (Bruzzese et al. 2010, Hájek and Adamec 2010). Additionally, the lightresponse curves are characteristic of both shade-adapted plants (Ögren 1993, Hikosaka and Terashima 1995) and carnivorous plants in general (Bruzzese et al. 2010, Hájek and Adamec 2010). On large pitchers of other species, one study primarily sampled only the keel or used an excised portions of the wall, taken from the tube-shaped leaf of the pitcher (Hájek and Adamec 2010), and photosynthesis was measured using a typical clamp-type chamber. This study was important for understanding the morphology and physiology of a $S$. alata. This study demonstrates that it is possible to create custom chambers $(2.79 \mathrm{~L})$ large enough to accommodate unconventional leaf morphology, i.e., leaves greater than $15 \mathrm{~cm}$ tall and tube-shaped. Measurement of photosynthesis has not previously been 
reported on S. alata and only limited work with other whole leaves of carnivorous pitcher plants have been published. This study can now serve as a baseline for understanding the photosynthetic properties of larger leaves in the genus Sarracenia and other related genera. Future studies will focus on fitting the custom chamber with field-portable features to measure in situ photosynthesis. The successful use of a custom chamber was significant because gasexchange equipment accommodated whole leaves, up to $65 \mathrm{~cm}$ tall, of Sarracenia alata.

\section{References}

Anderson J.M., Chow W.S., Goodchild D.J.: Thylakoid membrane organization in sun/shade acclimation. - Aust. J. Plant Physiol. 15: 11-26, 1988.

Azuma W., Ishii H.R., Masaki T.: Height-related variations of leaf traits reflect strategies for maintaining photosynthetic and hydraulic homeostasis in mature and old Pinus densiflora trees. - Oecologia 189: 317-328, 2019.

Böhning R.H., Burnside C.A.: The effect of light intensity on rate of apparent photosynthesis in leaves of sun and shade plants. Am. J. Bot. 43: 557-561, 1956.

Brewer J.S.: The lack of favorable responses of an endangered pitcher plant to habitat restoration. - Restor. Ecol. 13: 710717,2005

Brewer J.S., Baker D.J., Nero A.S. et al.: Carnivory in plants as a beneficial trait in wetlands. - Aquat. Bot. 94: 62-70, 2011.

Bruzzese B., Bowler R., Massicotte H., Fredeen A.: Photosynthetic light response in three carnivorous plant species: Drosera rotundifolia, D. capensis and Sarracenia leucophylla. - Photosynthetica 48: 103-109, 2010.

Dale M.P., Causton D.R.: Use of the chlorophyll $a / b$ ratio as a bioassay for the light environment of a plant. - Funct. Ecol. 6: 190-196, 1992.

Ellison A.M., Gotelli N.J.: Nitrogen availability alters the expression of carnivory in the northern pitcher plant, Sarracenia purpurea. - P. Natl. Acad. Sci. USA 99: 44094412, 2002.

Farquhar G.D., von Caemmerer S., Berry J.A.: A biochemical model of photosynthetic $\mathrm{CO}_{2}$ assimilation in leaves of $\mathrm{C}_{3}$ species. - Planta 149: 78-90, 1980.

Givnish T.J., Burkhardt E.L., Happel R.E., Weintraub J.D.: Carnivory in the bromeliad Brocchinia reducta, with a cost/ benefit model for the general restriction of carnivorous plants to sunny, moist, nutrient-poor habitats. - Am. Nat. 124: 479497, 1984.

Hájek T., Adamec L.: Photosynthesis and dark respiration of leaves of terrestrial carnivorous plants. - Biologia 5: 69-74, 2010.

He J., Zain A.: Photosynthesis and nitrogen metabolism of Nepenthes alata in response to inorganic $\mathrm{NO}_{3}^{-}$and organic prey $\mathrm{N}$ in the greenhouse. - ISRN Botany 2012: 263270, 2012.

Hikosaka K., Terashima I.: A model of the acclimation of photosynthesis in the leaves of $\mathrm{C}_{3}$ plants to sun and shade with respect to nitrogen. - Plant Cell Environ. 18: 605-618, 1995.

Inskeep W.P., Bloom P.R.: Extinction coefficients of chlorophyll $a$ and $b$ in N,N-dimethylformamide and $80 \%$ acetone. - Plant Physiol. 77: 483-485, 1985.

Jones R.: Sarracenia alata Wood: Surface Anatomy of Mature Leaves and Seed Germination Requirements. Pp. 71. Available from: ProQuest Dissertations \& Theses Global, Order \#1458374, 2008.

LI-COR Biosciences: Interfacing Custom Chambers to the Li-6400/XT Sensor Head. Application Note \#3. Pp. 8. Li-Cor Inc., Lincoln 2016. Available at: https://www.licor.com/ documents/xbd1mtavvz4yxoybyjnj.

Lobo F.B., de Barros M.P., Dalmagro H.J.: Fitting net photosynthetic light-response curves with Microsoft Excel a critical look at the models. - Photosynthetica 51: 445-456, 2013.

Lombardini L., Restrepo-Diaz H., Volder A.: Photosynthetic light response and epidermal characteristics of sun and shade pecan leaves. - J. Am. Soc. Hortic. Sci. 134: 372-378, 2009.

McDonald J.H.: Handbook of Biological Statistics ( $3^{\text {rd }}$ edition). Pp. 317. Sparky House Publishing, Baltimore 2014.

McPherson, S.: Pitcher Plants of the Americas. Pp. 320. The McDonald and Woodward Publishing Company, Blacksburg 2007.

Méndez M., Karlsson P.S.: Costs and benefits of carnivory in plants: Insight from the photosynthetic performance of four carnivorous plants in a subarctic environment. - Oikos 86: 105-112, 1999.

Mielke M.S., Schaffer B., Li C.: Use of a SPAD meter to estimate chlorophyll content in Eugenia uniflora L. leaves as affected by contrasting light environments and soil flooding. Photosynthetica 48: 332-338, 2010.

Norman J., Welles J., McDermitt D.: Estimating Canopy Lightuse and Transpiration Efficiencies from Leaf Measurements. Li-Cor Application Note \#105. Pp. 19. Li-Cor Inc., Lincoln 1992.

Ögren E.: Convexity of the photosynthetic light-response curve in relation to intensity and direction of light during growth. Plant Physiol. 101: 1013-1019, 1993.

Pavlovič A.: Photosynthetic characterization of Australian pitcher plant Cephalotus follicularis. - Photosynthetica 49: 253-258, 2011.

Pearcy R.W., Ehleringer J.: Comparative ecophysiology of $\mathrm{C}_{3}$ and $\mathrm{C}_{4}$ plants. - Plant Cell Environ. 7: 1-13, 1984.

Pessarakli M. (ed.): Handbook of Photosynthesis ( $2^{\text {nd }}$ edition). Pp. 846. CRC Press, Boca Raton 2005.

Schnell D.E.: Carnivorous Plants of the United States and Canada. $2^{\text {nd }}$ edition. Pp. 468. Timber Press, Portland 2002.

Wakefield A.E., Gotelli N.J., Wittman S.E., Ellison A.E.: Prey addition alters nutrient stoichiometry of the carnivorous plant Sarracenia purpurea. - Ecology 86: 1737-1743, 2005.

Yiotis C., Evans-Fitz.Gerald C., McElwain J.C.: Differences in the photosynthetic plasticity of ferns and Ginkgo grown in experimentally controlled low $\left[\mathrm{O}_{2}\right]:\left[\mathrm{CO}_{2}\right]$ atmospheres may explain their contrasting ecological fate across the TriassicJurassic mass extinction boundary. - Ann. Bot.-London 119: 1385-1395, 2017.

(C) The authors. This is an open access article distributed under the terms of the Creative Commons BY-NC-ND Licence. 